\title{
ASSESSMENT OF IMPACT OF EARLY STROKE REHABLLITATION ON HIP JOINT MOBLLITY OF THE AFFECTED LEG IN PATIENTS AFTER CEREBROVASCULAR ACCIDENTS
}

\author{
Wioletta Łubkowska, 1, A, C, D, E Tomasz Zdeb, 2, A,B,C Bożena Mroczek3, A, C, D \\ ${ }^{1}$ Faculty of Physical Education and Health Promotion, University of Szczecin, Poland \\ ${ }^{2}$ Medical Clinic Spondylus, Szczecin, Poland \\ ${ }^{3}$ Department of Humanities in Medicine, Faculty of Health Sciences, Pomeranian Medical University in Szczecin, Poland

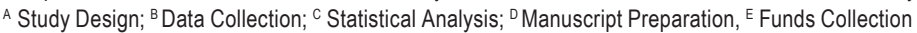

\author{
Address for correspondence: \\ Wioletta Łubkowska \\ University of Szczecin, Faculty of Physical Education and Health Promotion \\ Al. Piastów 40B, building 6, 71-065 Szczecin, Poland \\ E-mail: wioletta.lubkowska@univ.szczecin.pl
}

\begin{abstract}
Ahstract. One of the main priorities of stroke rehabilitation is regaining patients' independence in basic everyday activities. This paper is aimed at assessing impact of early stroke rehabilitation on hip joint mobility of the affected leg in patients after cerebrovascular accidents. The study included 30 subjects ( 13 men and 17 women) aged on average \pm 66.1 , with hemiparesis, who were treated at the stroke unit and participated in a 4-week rehabilitation program. Measurements of passive and active motion ranges were conducted with a goniometer in both limbs: healthy and affected ones by stroke. There were statistically significant differences in motion ranges between healthy and affected limbs. Examination I revealed that affected limbs amounted to only $40 \%$ of physiological range, while in Examination II, the result reached $73 \%$. The most significant motion limitations were noted in terms of bending, adduction and internal rotation, while the least significant in terms of external rotation and abduction. Exercises used during early stroke rehabilitation of hemiparesis patients considerably increased active motion ranges and maintained passive motion ranges in the hip joint of the affected limb. Patients with right-sided hemiparesis experienced much better improvement in hip joint motion of the affected limb. The 4-week period was insufficient to mobilize patients and help them regain full active mobility in the hip joint of the affected limb. These patients required further physiotherapy, until they fully regained functionality.
\end{abstract}

KeV Worlls: stroke rehabilitation, stroke, kinesiotherapy, physiotherapy, motion range, hip joint

\section{Introduction}

Stroke is a sudden clinical syndrome characterized by sudden, partial or overall disorder of brain functions, whose symptoms last for more than 24 hours or lead to death within this time, and have no other cause than vascular (The WHO 1988). Recently, the term 'cerebrovascular accident' (CVA) has been used increasingly frequently instead of the term 'stroke'. Nowadays, stroke is one of the most severe health problems, as it is the 
3rd most common cause of death (4th in Poland) (Grochulska and Jastrzębska 2012). It also leads to severe and chronic disability, which results in social and economic problems (Członkowska et al. 2006; Kwolek et al. 2005). Stroke has numerous and severe consequences. It is estimated that $15-30 \%$ of stroke patients remain disabled for life (Schwamm et al. 2005), while $50 \%$ of them require 3rd person assistance due to limited physical and mental ability (Jaracz and Kozubski 2006). Stroke often results in hemiparesis, i.e. partial loss of muscle strength resulting from damage to the corticobulbar tract, usually near the internal capsule, which affect half of the body (side opposite to the brain damage) (Mazur 2007). Therefore, the key issue is an overall, holistic hospital and outpatients care (Mazurek et al. 2013), which relies heavily on comprehensive stroke rehabilitation (Członkowska et al. 2006). Rehabilitation must be treated as an important element of treatment, which should be implemented as soon as possible. According to Experts' Group, it should commence 1-2 day after the stroke, as soon as the patient stabilizes. It should tackle mobility deficit (mobilizing exercises) and higher nervous activities (Wiszniewska et al. 2012), which reduces disability, improves life quality, helps attain maximally improved motor skills, enables the patient to walk and reduces tonus (Członkowska et al. 2006; Kwolek et al. 2005). According to Flis and Bejer (2014), improved balance and learning to walk again is one of main aims of stroke rehabilitation.

Research indicates that treating acute stroke, especially at stroke units, correlates with better prognosis and significant reduction of mortality after stroke (Stroke Unit Trialists' Collaboration 2013).

According to Helsingborg Declaration, the aim of rehabilitation (to be attained by 2015), is regaining independence in basic everyday activities in $70 \%$ of patients within 3 months after stroke (Kjellstrom et al. 2007).

This paper is aimed at assessing impact of early stroke rehabilitation on hip joint mobility of the affected leg in patients after cerebrovascular accidents.

\section{Material and methods}

This study included 30 patients (13 men and 17 women) who suffered from stroke. They were rehabilitated in Regional Hospital in Kołobrzeg, Poland, at stroke unit in an increased medical care room, which provides stroke patients with the highest medical standards. $56.7 \%(n=17)$ of subjects suffered from right-sided hemiparesis, while $43.3 \%$ ( $n=13$ ) - from left-sided hemiparesis. Patients were divided into two groups, based on the affected side. Group A included patients with right-sided hemiparesis, and Group B consisted of subjects with left-sided hemiparesis. $53.3 \%$ of subjects suffered from stroke caused by clots in brain arteries, $40 \%$ suffered from transient ischemic attack, while $6.7 \%$ suffered from embolism in cerebral arteries.The average age of subject was \pm 66.1 (34-85). On average, subjects spent 28 day at the stroke unit.

The study included measurements of active and passive motion ranges of hip joints of healthy and affected legs; measurements were made with goniometer (measurement accuracy: $1^{\circ}$ ). Measurements followed widely accepted standards (Rosławski and Skolimowski 2000).The following movements in the hip joint were measured: bending, straightening in horizontal axis, abduction and adduction around axis sagittalis, as well as external and internal rotation in vertical axis.

Rehabilitation process was continuous and employed Kabat Method of Exercise, known as Proprioceptive Neuromuscular Facilitation (PNF). Other methods and techniques were also used (Brunnstrom, Rood, Bobatch's methods) in various sets of exercises, depending on mobility and regained functionality of patients. Rehabilitation aimed at increasing motion ranges in peripheral joints in the affected limb. Subjects were rehabilitated every day with 
kinesiotherapy for 45 minutes. Rehabilitation consisted of compiled, specialized techniques adjusted individually to patients.

To statistically analyze the results of the study, standard methods were used (arithmetic mean, standard deviation, coefficient of variation). Hypothesis related to significance of differences between mean deviations for particular motion ranges were verified with statistical tests: for two averages (Student's t-distribution), Student's t-distribution of differences between correlated pairs.

\section{Results}

Passive motion ranges in the hip joint of the affected and healthy limb in Group A and Group B were similar in Examination I and Examination II (statistically insignificant differences at $\lambda=0.05$ ). Table 1 presents characteristics of active motion ranges in the hip joint of the healthy and affected limb in Examination I and II in Group A.

Table 1. Characteristics of active motion ranges of the hip joint in Examination I and II in Group A

\begin{tabular}{|c|c|c|c|c|c|c|c|c|c|c|c|c|c|c|c|}
\hline \multirow{4}{*}{ MOTION } & \multicolumn{6}{|c|}{ Examination I } & \multicolumn{9}{|c|}{ Examination II } \\
\hline & \multicolumn{6}{|c|}{ motion range $\left[\right.$ in $^{\circ}$ ] } & \multicolumn{7}{|c|}{ motion range [in ${ }^{\circ}$ ] } & \multirow{3}{*}{ t2 } & \multirow{3}{*}{$\mathrm{t} 3$} \\
\hline & \multicolumn{3}{|c|}{ affected limb } & \multicolumn{3}{|c|}{ healthy limb } & \multirow[t]{2}{*}{$\mathrm{t} 1$} & \multicolumn{3}{|c|}{ affected limb } & \multicolumn{3}{|c|}{ healthy limb } & & \\
\hline & mean & SD & Vs & mean & SD & Vs & & mean & SD & Vs & mean & SD & Vs & & \\
\hline Bending & 34.50 & 7.33 & 21.23 & 120.7 & 9.95 & 9.24 & $27.89^{*}$ & 77.0 & 12.69 & 16.49 & 121.5 & 9.52 & 7.83 & $11.25^{*}$ & $19.73^{*}$ \\
\hline Straightening & 6.00 & 2.30 & 38.85 & 17.8 & 1.39 & 7.85 & $17.50^{*}$ & 12.8 & 2.80 & 21.92 & 18.3 & 1.56 & 8.34 & $6.96^{*}$ & $16.00^{*}$ \\
\hline Abduction & 20.40 & 6.00 & 29.48 & 42.4 & 1.45 & 3.43 & $14.26^{*}$ & 34.2 & 7.82 & 24.64 & 42.9 & 1.53 & 3.37 & $4.34^{*}$ & $10.42^{*}$ \\
\hline Adduction & 9.24 & 4.05 & 43.97 & 25.4 & 2.37 & 9.37 & $13.73^{*}$ & 19.5 & 4.82 & 24.56 & 25.5 & 2.23 & 8.72 & $4.52^{*}$ & $13.95^{*}$ \\
\hline $\begin{array}{l}\text { Internal } \\
\quad \text { rotation }\end{array}$ & 24.50 & 3.43 & 13.99 & 42.3 & 3.39 & 8.02 & $14.73^{*}$ & 36.1 & 4.42 & 12.23 & 42.8 & 3.35 & 7.80 & $4.79^{*}$ & $15.61^{*}$ \\
\hline $\begin{array}{l}\text { External } \\
\text { rotation }\end{array}$ & 14.30 & 4.17 & 28.73 & 41.7 & 1.41 & 3.39 & $24.92^{\star}$ & 23.5 & 6.18 & 26.35 & 42.1 & 1.55 & 3.69 & $11.67^{*}$ & $9.49^{*}$ \\
\hline
\end{tabular}

${ }^{*}$ Statistically significant differences $(\lambda=0.05)$.

Mean - arithmetic mean value; SD - standard deviation; Vs - Variation coefficient.

$\mathrm{t} 1$ - Significance of differences between affected and healthy limb in Examination I;

t2 - Significance of differences between affected and healthy limb in Examination II;

t3 - significance of mean differences between affected limbs in Examinations I and II.

Analysis of mean motion ranges in affected and healthy limb obtained in Examination I indicated very significant differences. The affected limb had noticeably worse results. It amounted to only $40 \%$ of physiological range of movement. The most significant motion limitations were noted in terms of bending, adduction and internal rotation, while the least significant in terms of external rotation and abduction. Differences between affected and healthy limb were statistically significant. Examination II proved a significant increase of active motion range in the affected limbs. Nonetheless, they were still lower in comparison to the healthy limb, amounting to on average $73 \%$ of the physiological range. Calculated differences between affected and healthy limb were statistically significant. Examinations I and II proved a noticeable improvement in active motion ranges in hip joint of the affected limb. The improvement was statistically significant.

Table 2 presents characteristics of active motion ranges in the hip joint of the healthy and affected limb in Examination I and II in Group B. 
Table 2. Characteristics of active motion ranges of the hip joint in Examination I and II in Group B

\begin{tabular}{|c|c|c|c|c|c|c|c|c|c|c|c|c|c|c|c|}
\hline \multirow{4}{*}{ MOTION } & \multicolumn{6}{|c|}{ Examination I } & \multicolumn{9}{|c|}{ Examination II } \\
\hline & \multicolumn{6}{|c|}{ motion range [in ${ }^{\circ}$ ] } & \multicolumn{7}{|c|}{ motion range $\left[\right.$ in $^{\circ}$ ] } & \multirow{3}{*}{$\begin{array}{l}\text { motion } \\
\text { range } \\
{\left[\text { in }^{\circ} \text { ] }\right.}\end{array}$} & \multirow{3}{*}{ t1 } \\
\hline & \multicolumn{3}{|c|}{ affected limb } & \multicolumn{3}{|c|}{ healthy limb } & $\mathrm{t} 1$ & \multicolumn{3}{|c|}{ affected limb } & \multicolumn{3}{|c|}{ healthy limb } & & \\
\hline & mean & SD & Vs & mean & SD & Vs & & mean & SD & Vs & mean & SD & Vs & & \\
\hline Bending & 22.1 & 4.65 & 21.05 & 115.0 & 11.83 & 10.03 & $25.23^{*}$ & 42.4 & 7.50 & 17.7 & 116.1 & 11.2 & 9.65 & $18.93^{*}$ & $15.20^{*}$ \\
\hline Straightening & 1.2 & 1.24 & 101.00 & 17.5 & 0.92 & 5.20 & $36.77^{*}$ & 5.8 & 1.53 & 26.5 & 18.4 & 1.39 & 7.6 & $21.15^{*}$ & $14.56^{*}$ \\
\hline Abduction & 14.3 & 5.27 & 36.80 & 41.4 & 1.13 & 2.77 & $17.39^{*}$ & 23.7 & 6.57 & 27.7 & 41.9 & 1.07 & 2.56 & $9.49^{*}$ & $9.90^{*}$ \\
\hline Adduction & 3.9 & 1.03 & 26.70 & 24.1 & 2.20 & 9.10 & $28.95^{*}$ & 11.2 & 2.89 & 25.7 & 24.4 & 2.27 & 9.32 & $12.48^{*}$ & $12.0^{*}$ \\
\hline Internal rotation & 19.6 & 5.21 & 26.57 & 38.9 & 4.41 & 11.33 & $9.79^{*}$ & 27.8 & 4.37 & 15.7 & 39.8 & 4.23 & 10.06 & $6.86^{*}$ & $11.57^{*}$ \\
\hline $\begin{array}{l}\text { External } \\
\text { rotation }\end{array}$ & 10.5 & 2.60 & 19.56 & 12 & 1.32 & & & & 2.79 & & 41.6 & 186 & 445 & & \\
\hline
\end{tabular}

* Statistically significant differences $(\lambda=0.05)$.

Mean - arithmetic mean value; SD - standard deviation; Vs - Variation coefficient.

$\mathrm{t} 1$ - Significance of differences between affected and healthy limb in Examination I;

t2 - Significance of differences between affected and healthy limb in Examination II;

t3 - significance of mean differences between affected limbs in Examinations I and II.

Examination I revealed very significant limitations of active motion of the affected limb. Active motion in the hip joint of the affected leg on average amounted to $24 \%$ of physiological range. The biggest mobility limitations were observed in terms of straightening, adduction and bending, while the least limited motions were external rotation and abduction. There were statistically significant differences noted. Examination II proved an increase of active motion range in the affected limb. Nevertheless, they were lower than healthy limb motion ranges. They amounted only to $45 \%$ of the physiological ranges (with statistically significant differences). The observed improvement of active motion in the hip joint in the affected limb was statistically significant.

Figures 1 and 2 present analysis of active motion ranges in the hip joint in the affected limb in Group $A$ and $B$ in Examination I and II. Based on Examination I, Group B faced greater limitation of active motion ranges in the hip joint than Group A. Examination II showed that despite improved active motion ranges in the hip joint in patients in both groups, the difference between groups persisted. Patients with right-sided hemiparesis experienced much better improvement in hip joints of the affected limb (Group A).

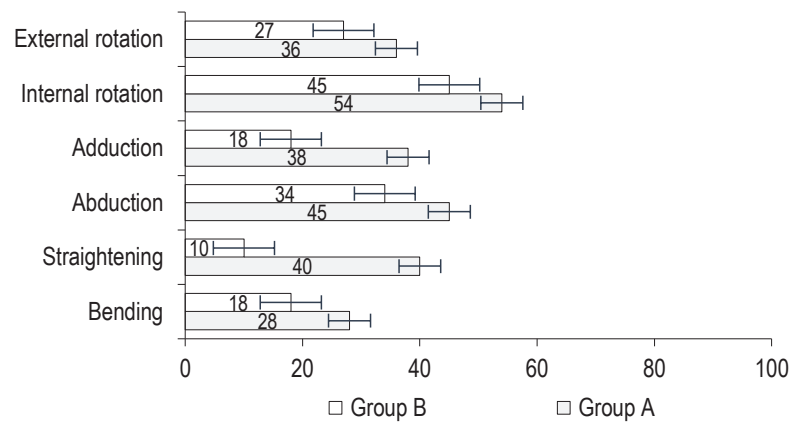

Figure 1. Comparison of active motion ranges in the hip joint in Group A and B in Examination I [\%] 


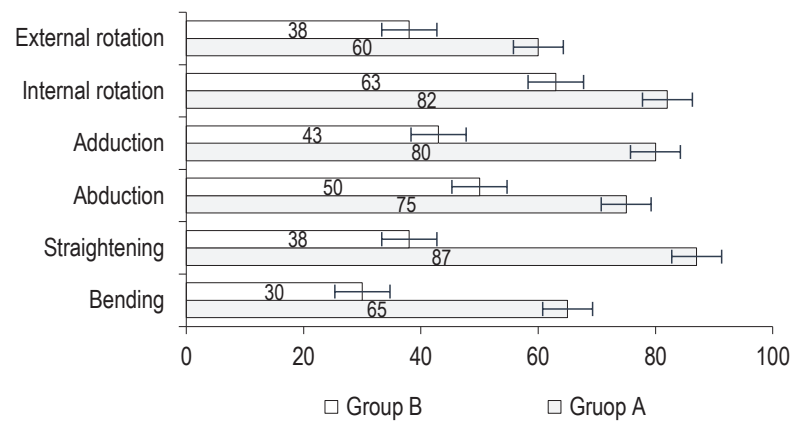

Figure 2. Comparison of active motion ranges in the hip joint in Group A and B in Examination II [\%]

\section{Discussion}

According to the Helsingborg Declaration, shortly after stroke, all patients should have the right to rehabilitation without preselection (Postępowanie w udarze mózgu 2008). Guidelines for early rehabilitation of stroke patients assume everyone is treated from the beginning as if they were to fully regain lost functions (Nyka and Jankowska 2009).

Considering current medical advances, the role of early, continuous, comprehensive and easily available rehabilitation is obvious (Kwolek 2005; Mazurek 2013). 90\% of stroke patients qualify for continued rehabilitation at a rehabilitation unit. Kwolek team's study (2005) showed that there are no explicit and irreversible counter indications for rehabilitation. Study by Grochulska and Jastrzębska (2012) revealed that after release from hospital, only approximately $50 \%$ of patients participated in rehabilitation at rehabilitation units; $17 \%$ continued the process of rehabilitation with a privately hired rehabilitation specialist, while every third stroke patient discontinued the process of rehabilitation for various reasons.

In practice, the rehabilitation process which started at the stroke unit should be professionally continued at a neurological rehabilitation unit, where early stroke rehabilitation is offered, which should last for 3-9 weeks. The continuation of the therapy should focus on perfecting the ability to walk and change positions, and on stimulating functionality. Patients who completed early stroke rehabilitation (2-3 months after stroke), should be able to walk on their own or with little assistance. Walk should include active bend of the hip joint. Poland faces the problem of insufficient number of rehabilitation beds; patients are often released with a list of rehabilitation recommendations which are difficult to meet in practice (Nyka and Jankowska 2009). Therefore, the key factor of successful rehabilitation is its comprehensiveness and easy availability. Unfortunately, study by Mazurek et al. (2013) showed that only a small proportion of neurology wards (14\%) and rehabilitation wards (10\%) in Poland offer comprehensive stroke rehabilitation.

The Expert Committee of the National Program of Prevention and Treatment of Stroke recommended short sessions of physiotherapy (e.g. 10-15 minutes) but with many repetitions (e.g. 6 times per day) so that in total physiotherapy lasts for at least 45 minutes daily (Członkowska et al. 2006). In Germany, the recommended minimum time of rehabilitation care of patients who were transferred from intensive care unit is 4 hours (Bundesarbeitsgemeinschaft für Rehabilitation 1995). 
In this study a 4-week rehabilitation treatment was assessed. The examination of patients revealed that the 4-week period was insufficient to mobilize patients and help them regain full active motion in the hip joint of the affected limb. Patients required further rehabilitation. Kinesiotherapy should be the key element of such treatment (Jajor et al. 2013), as well as modern therapies and rehabilitation techniques for disabled patients. Karakiewicz et al. (2011) noted positive impact of computer programs as auxiliary therapy for improving cognitive functions of patients who suffered from ischemic stroke. It has been established that cognitive disorders constitute a considerable barrier and may negatively influence rehabilitation success rate (Luk 2012).

An alternative method of reducing disorders caused by neurological diseases is aquatic rehabilitation (Jajor et al. 2013). Water creates favorable conditions for the human body (Łubkowska et al. 2015; Nalazek et al. 2015). Due to its beneficial effects, water offers a positive environment to conduct therapy of neuromuscular diseases, such as stroke. Used for neurologic diseases, the aquatic therapy strengthens muscle groups, improves joint motion ranges, improves balance, lowers or strengthens tonus, and reduces pain (Becker 2009). Study of hemiparesis patients revealed that it was possible to speed up the process of teaching them to walk by strengthening muscles, improving blood flow and overall fitness (Chon et al. 2009; Nowotny-Czupryna 2001).

\section{Conclusions}

1. Hemiparesis patients who suffered from stroke and were included into early physiotherapy treatments showed considerable improvement of active motion ranges and maintained passive motion ranges in the hip joint of the affected limb.

2. Patients with right-sided hemiparesis experienced much better improvement in hip joint motion of the affected limb.

3. The 4-week period was insufficient to mobilize patients and help them regain full active mobility in the hip joint of the affected limb. These patients required further physiotherapy, until they fully regained functionality.

\section{References}

Becker B.E. Aquatic Therapy: Scientific foundations and clinical rehabilitation Applications. Am Acad Physical Med Rehab. $2009 ; 1$ (9): 859-872.

Bundesarbeitsgemeinschaft für Rehabilitation. Empfehlungen zur Neurologischen Rehabilitation von Patienten mit seweren und schwersten Hirnschädigungen in den Phasen B und C. Vom 2. November 1995.

Chon Ch.S, Oh W.D, Shim H.J. Watsu approach for improving spasticity and ambulatory function in hemiparetic patients with stroke. Physiother Res Int. 2009; 14 (2): 128-136.

Członkowska A., Sarzyńska-Długosz I., Krawczyk M. An evaluation of the accessibility of early post-stroke comprehensive rehabilitation in Poland. Neurol Neuroch Pol. 2006; 40 (1): 10-15.

Flis D., Bejer A. The influence of chosen clinical and demografic factors on progress in reeducation of balance and walk of people after stroke. Adv Rehabil 2014; 27 (4): 31-39.

Grochulska A., Jastrzębska M. Improvement in functional performance of people suffering from brain stroke - the role of a nurse. Probl Pielęg. 2012; 20 (3): 300-309.

Jajor J., Nonn-Wasztan S., Rostkowska E., Samborski W. Specifics of movement rehabilitation in the elderly. Now Lek. $2013 ; 82$ (1): 89-96.

Jaracz K., Kozubski W. Znaczenie wsparcia społecznego dla jakości życia chorych po udarze mózgu. Neurol Neuroch Pol. $2006 ; 40$ (2): 140-150.

Karakiewicz B., Żułtak-Bączkowska K., Mroczek B. Modern ways of therapy and rehabilitation of disabled persons - computer supported rehabilitation of cognitive functions among patients after neurological problems. Przew Lek. 2011; 1: 231-234. 
Kjellstrom T., Norrving B., Shatchkute A. Helsingborg Declaration 2006 on European stroke strategies. Cerebrovasc Dis. 2007; 23 (2-3): 231-241.

Kwolek A., Szydełko M., Domka E. The limits of contraindications to post-stroke rehabilitation. Udar Mózgu. $2005 ; 7$ (1): 31-37.

Luk J.H.K. Rehabilitation in older people: know more, gain more. Hong Kong Med J. 2012; 18 (1): 56-59.

Łubkowska W., Szark-Eckardt M., Żukowska H. The application of the Halliwick concept in therapeutic and corrective swimming. In: Psychomotor Therapy and Physical Self-Concept, eds. T. Louková, B. Hátlová, A. Adámková Ségard. University of J.E. Purkyné in Usti nad Labem, Czech 2015: 109-118.

Mazur R. (eds.) Neurologia kliniczna. Via Medica, Gdańsk 2007.

Mazurek J., Blaszkowska A., Rymaszewska J. Rehabilitation after stroke - current guidelines. Now Lek. $2013 ; 82$ (1): 83-88.

Nalazek A., Szark-Eckardt M., Gawinecka-Mykaj B., Łubkowska W. A comprehensive approach to water treatment. In: Stan, perspektywy i rozwój ratownictwa, kultury fizycznej i sportu w XXI wieku, t. II, eds. M. Napierała, A. Skaliy. Problemy Kultury Fizycznej i Sportu. University of Economy, Bydgoszcz 2015: 372-377.

Nowotny-Czupryna O., Rudzińska A., Czupryna K., Lambeck J. Możliwości zastosowania terapii w wodzie u pacjentów z niektórymi dysfunkcjami narządu ruchu. Fizjoter Pol. 2001; 1 (1): 67-73.

Nyka W., Jankowska B. Zasady wczesnej rehabilitacji chorych z udarem niedokrwiennym mózgu. Forum Med Rodz. 2009 ; 3 (2): 85-91.

Postępowanie w udarze mózgu. Wytyczne Grupy Ekspertów Narodowego Programu Profilaktyki i Leczenia Chorób Układu SercowoNaczyniowego POLKARD. Neurol Neuroch Pol. 2008; 4 (supl. 3): 203-288.

Rosławski A., Skolimowski T. Badania czynnościowe w kinezyterapii. Wrocław: Wydawnictwo AWF Wrocław 2000.

Schwamm L.H., Pancioli A., Acker J.E., Goldstein L.B., Zorowitz R.D., Shephard T.J., Moyer P., Gorman M., Johnston S.C., Duncan P.W., Gorelick P., Frank J., Stranne S.K., Smith R., Federspiel W., Horton, K.B., Magnis E., Adams R.J. Recommendations for the Establishment of Stroke Systems of Care: Recommendations From the American Stroke Association's Task Force on the Development of Stroke Systems. Stroke. 2005; 36 (3): 690-703.

Stroke Unit Trialists' Collaboration. Organised inpatient (stroke unit) care for stroke. Cochrane Database of Systematic Reviews 2013; 9 (CD000197).

The World Health Organization MONICA Project (monitoring trends and determinants in cardiovascular disease): a major international collaboration. WHO MONICA Project Principal Investigators. J Clin Epidemiol. 1988; 41 (2): 105-114.

Wiszniewska M., Kobayashi A., Członkowska A. Postępowanie w udarze mózgu. Skrót Wytycznych Grupy Ekspertów Sekcji Chorób Naczyniowych Polskiego Towarzystwa Neurologicznego z 2012 roku. Pol Prz Neurol. 2012; 8 (4): 161-175.

Cite this article as: Łubkowska W., Zdeb T., Mroczek B. Assessment of Impact of Early Stroke Rehabilitation on Hip Joint Mobility of the Affected Leg in Patients after Cerebrovascular Accidents. Central European Journal of Sport Sciences and Medicine. 2015; 12 (4): 17-23. 
